\title{
Agronomic Package for Container Grown Elephant Foot Yam
}

\author{
N. P. Limisha* and O. K. Swadija \\ College of Agriculture, Vellayani, Thiruvananthapuram - 695522, India \\ *Corresponding author
}

\section{Ke y w o r d s \\ Elephant foot yam, Container cultivation, Organic farming, Growth media, Irrigation schedule}

\section{Article Info}

\section{Accepted:}

10 July 2020

Available Online:

10 August 2020

\section{A B S T R A C T}

An investigation entitled Agronomic package for container grown elephant foot yam was undertaken at College of Agriculture (KAU), Vellayani, Thiruvananthapuram, to standardize growth medium and nutrient and irrigation schedule for elephant foot yam grown in containers. The experiment was done by raising elephant foot yam var. Gajendra in plastic sacks of uniform size with 12 treatment combinations involving three growth media $\left(\mathrm{M}_{1}\right.$ - soil : sand : FYM 1:1:1, $\mathrm{M}_{2}$ - soil : coir pith : FYM 1:1:1 and $\mathrm{M}_{3}$ - soil : coir pith : FYM 0.75:1.25:1), two nutrient schedule $\left(\mathrm{N}_{1}-\mathrm{N}\right.$ and $\mathrm{K}$ in three splits and $\mathrm{N}_{2}-\mathrm{N}$ and $\mathrm{K}$ in six splits $)$ and two irrigation schedule $\left(\mathrm{I}_{1}\right.$ - irrigation once in three days and $\mathrm{I}_{2}$ irrigation once in six days) with four replications in completely randomized design . Based on the results of the study, a cost effective agronomic package for container cultivation of elephant foot yam was formulated. Plastic sacks of uniform size filled with 9 $\mathrm{kg}$ soil $+3 \mathrm{~kg}$ coir pith $+3 \mathrm{~kg}$ FYM can be used as containers. Apply lime @ $10 \mathrm{~g}$ and neem cake@100 g sack ${ }^{-1}$ and bring the moisture content of growth medium to field capacity. Plant corm pieces of $250 \mathrm{~g}$ ( treated with Trichoderma - cow dung slurry and shade dried) in each sack. Apply the recommended dose of $100: 50: 150 \mathrm{~kg} \mathrm{NPK} \mathrm{ha}^{-1}$ for elephant foot yam through organic manures like groundnut cake, bone meal and wood ash. Apply $10 \mathrm{~g}$ of bone meal sack ${ }^{-1}$ as basal dose and $50 \mathrm{~g}$ of groundnut cake and $100 \mathrm{~g}$ of wood ash sack ${ }^{-1}$ in six splits at monthly interval starting from one month after planting. Irrigate the crop once in three days during non - rainy periods.

\section{Introduction}

In the present context of shrinking land area available for cultivation especially in urban areas, the container cultivation is becoming popular. In urban areas, container cultivation is mainly adopted for raising vegetables, that ensures safe and fresh produce for household consumption and also avoids tedious field work and enables efficient utilization of nutrients and moisture by the plant in the container. The elephant foot yam, an important tuberous vegetable with good keeping quality and nutritive values can be raised in containers in the available space around houses or on house terraces. Organic farming is the thumb rule for raising crops on house terrace in containers and an ideal growth medium is also necessary for container cultivation. At present, technology 
for organic production of elephant foot yam in containers is lacking. In this background, the present study was undertaken at College of Agriculture (KAU), Vellayani, Thiruvananthapuram to formulate a cost effective agronomic package for container cultivation of elephant foot yam.

\section{Materials and Methods}

The experiment was conducted during April to November 2016 by raising elephant foot yam var. Gajendra in plastic sacks with 12 treatment combinations involving three growth media $\left(\mathrm{M}_{1}\right.$ - soil : sand : FYM 1:1:1, $\mathrm{M}_{2}$ - soil : coir pith : FYM 1:1:1 and $\mathrm{M}_{3}$ - soil : coir pith : FYM 0.75:1.25:1), two nutrient schedule $\left(\mathrm{N}_{1}-\mathrm{N}\right.$ and $\mathrm{K}$ in three splits and $\mathrm{N}_{2}$ $-\mathrm{N}$ and $\mathrm{K}$ in six splits) and two irrigation schedule $\left(\mathrm{I}_{1}\right.$ - irrigation once in three days and $\mathrm{I}_{2}$ - irrigation once in six days) with four replications in completely randomized design. Different growth media used in the experiment were prepared with soil, sand, FYM and coir pith in different proportions by volume .The growth medium $\mathrm{M}_{1}$ was prepared by mixing $9 \mathrm{~kg}$ soil, $8 \mathrm{~kg}$ sand and 3 $\mathrm{kg}$ FYM, $\mathrm{M}_{2}$ with $9 \mathrm{~kg}$ soil, $3 \mathrm{~kg}$ coir pith and $3 \mathrm{~kg}$ FYM and $\mathrm{M}_{3}$ with $7 \mathrm{~kg}$ soil, $3.75 \mathrm{~kg}$ coir pith and $3 \mathrm{~kg}$ FYM. Lime @ 10g and neem cake @100g sack ${ }^{-1}$ were applied initially in all growth media. Initially, the moisture content of growth media was brought to field capacity. Corm pieces of $250 \mathrm{~g}$, treated with Trichoderma - cow dung slurry and shade dried, were planted in each sack during April 2016.The recommended dose of 100:50:150 $\mathrm{kg} \mathrm{NPK} \mathrm{ha}{ }^{-1}$ for elephant foot yam (KAU, 2011) was applied to each sack through organic manures like groundnut cake, bone meal and wood ash. The calculated quantities of groundnut cake $(50 \mathrm{~g})$, bone meal $(10 \mathrm{~g})$ and wood ash (100 g) based on their nutrient contents were applied in each sack. Uniform dose of bone meal was applied as a single basal dose in all sacs prior to planting of corm. Groundnut cake was made into 10 per cent slurry with water, fermented for three days and mixed with wood ash and applied in three splits (1, 3 and 5 months after planting)or in six splits $(1,2,3,4,5$ and 6 months after planting). The crop was harvested seven months after planting. The observations on corm yield sack ${ }^{-1}$ were taken at harvesting. The economics of cultivation was worked out, in terms of net income and benefit cost ratio, by taking into account the cost of inputs and market price of elephant foot yam during the cropping period.

\section{Results and Discussion}

The highest corm yield of $2041.67 \mathrm{~g} \mathrm{plant}^{-1}$ (Fig. 1) was obtained in the growth medium $\mathrm{M}_{2}$ (soil : coir pith : FYM 1:1:1) in which $\mathrm{N}$ and $\mathrm{K}$ were applied in six splits $\left(\mathrm{N}_{2}\right)$ and given more frequent irrigation $\left(\mathrm{I}_{1}\right.$ - irrigation once in three days) during non-rainy periods. The results revealed the feasibility of substitution of costlier sand in the growth medium with coir pith and the need for more split application of $\mathrm{N}$ and $\mathrm{K}$ and frequent irrigation for elephant foot yam raised in containers.

By planting corm pieces weighing $250 \mathrm{~g}$, it was possible to harvest corm yield ranging from 1083.33 to $2041.67 \mathrm{~g} \mathrm{plant}^{-1}$ under the influence of the treatments (Fig. 1). The corm bulking efficiency (ratio of final corm weight to weight of the seed corm) ranged from 4.3 to 8.2. According to Ravi et al., (2011), the corm bulking efficiency varied with type of seed corm (cut or whole), seed corm weight and spacing adopted. With corm piece weighing $250 \mathrm{~g}$, James and Nair (1993) have obtained corm bulking efficiency of 3 to 4.6 under varied spacing in the field. Hence, higher corm bulking efficiency realized in the present study indicated better yield of elephant foot yam from organic cultivation in containers. Higher yield of elephant foot yam 
under organic cultivation has been reported by Suja et al., (2010 and 2012).

A close scrutiny of data presented in Table 1 indicated the significant effects of treatments on net income as well as on BCR. The results of the study revealed that the best growth medium for container cultivation of elephant foot yam is soil, coir pith and FYM in 1:1:1 ratio by volume $(9 \mathrm{~kg}$ soil $+3 \mathrm{~kg}$ coir pith +3 kg FYM). Large difference in net income and BCR between the growth media had occurred due to the difference in corm yield obtained from them and cost of each growth medium. The highest corm yield of $1760.42 \mathrm{~g} \mathrm{plant}^{-1}$ was obtained from the growth medium $\mathrm{M}_{2}$ followed by $\mathrm{M}_{1}\left(1629.17 \mathrm{gplant}^{-1}\right)$. All other inputs (plastic sack, lime, neem cake, Trichoderma, groundnut cake, bone meal, wood ash and Pseudomonas) except the growth medium being common, the cost of
$\mathrm{M}_{1}$ was Rs.39 sack $^{-1}$ (due to high cost of sand), of $\mathrm{M}_{2}$ was Rs.24 sack $^{-1}$ and of $\mathrm{M}_{3}$ Rs.26.25 sack $^{-1}$ (due to cost of additional quantity of coir pith).

Appreciably higher net income and BCR could be obtained due to application of $\mathrm{N}$ and $\mathrm{K}$ in six splits $\left(\mathrm{N}_{2}\right)$ rather than three splits $\left(\mathrm{N}_{1}\right)$ and irrigation once in three days $\left(\mathrm{I}_{1}\right)$ due to higher corm yield produced by $\mathrm{N}_{2}$ and $\mathrm{I}_{1}$ treatments. The highest net income of Rs.38.47 sack $^{-1}$ (Fig. 2) and BCR of 1.89 (Fig. 3 ) could be obtained when $\mathrm{M}_{2}$ was used as the growth medium with six split application of $\mathrm{N}$ and $\mathrm{K}$ and irrigation once in three days $\left(\mathrm{m}_{2} \mathrm{n}_{2} \mathrm{i}_{1}\right.$ with corm yield of $\left.2041.67 \mathrm{~g} \mathrm{plant}^{-1}\right)$. The next best net income of Rs.30.8 sack $^{-1}$ and BCR of 1.71 was obtained with $\mathrm{M}_{2}$ as growth medium, three splits of $\mathrm{N}$ and $\mathrm{K}$ and irrigation once in three days $\left(\mathrm{m}_{2} \mathrm{n}_{1} \mathrm{i}_{1}\right)$.

Table.1 Effect of growth medium, nutrient schedule and irrigation schedule on corm yield and economics of cultivation

\begin{tabular}{|c|c|c|c|}
\hline Treatments & $\begin{array}{l}\text { Corm yield } \\
\left(\text { g plant }^{-1}\right)\end{array}$ & $\begin{array}{c}\text { Net income } \\
\left(\text { Rs. } \text { sack }^{-1}\right)\end{array}$ & BCR \\
\hline \multicolumn{4}{|l|}{ Growth medium (M) } \\
\hline$M_{1}$ - soil : sand : FYM 1:1:1 & 1629.17 & 6.97 & 1.12 \\
\hline $\mathrm{M}_{2}-$ soil : coir pith : FYM 1:1:1 & 1760.42 & 27.22 & 1.63 \\
\hline 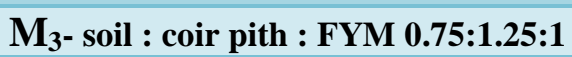 & 1383.33 & 9.88 & 1.22 \\
\hline SEm \pm & 34.882 & 1.395 & 0.030 \\
\hline $\mathrm{CD}(\mathbf{0 . 0 5})$ & 101.810 & 4.074 & 0.088 \\
\hline \multicolumn{4}{|l|}{ Nutrient schedule (N) } \\
\hline$N_{1}-N \& K$ in 3 splits & 1531.94 & 12.33 & 1.27 \\
\hline$N_{2}-N \& K$ in 6 splits & 1650.00 & 17.05 & 1.37 \\
\hline SEm \pm & 28.481 & 1.139 & 0.025 \\
\hline $\mathrm{CD}(\mathbf{0 . 0 5})$ & 83.130 & 3.326 & 0.072 \\
\hline \multicolumn{4}{|l|}{ Irrigation schedule (I) } \\
\hline$I_{1}$ - Irrigation once in 3 days & 1773.61 & 21.99 & 1.47 \\
\hline$I_{2}$ - Irrigation once in 6 days & 1408.33 & 7.38 & 1.17 \\
\hline SEm \pm & 28.481 & 1.139 & 0.025 \\
\hline $\mathrm{CD}(\mathbf{0 . 0 5})$ & 83.130 & 3.326 & 0.072 \\
\hline
\end{tabular}


Fig.1 Effect of growth medium (M), nutrient schedule $(\mathrm{N})$ and irrigation schedule (I) on corm yield plant $^{-1}$ at harvest

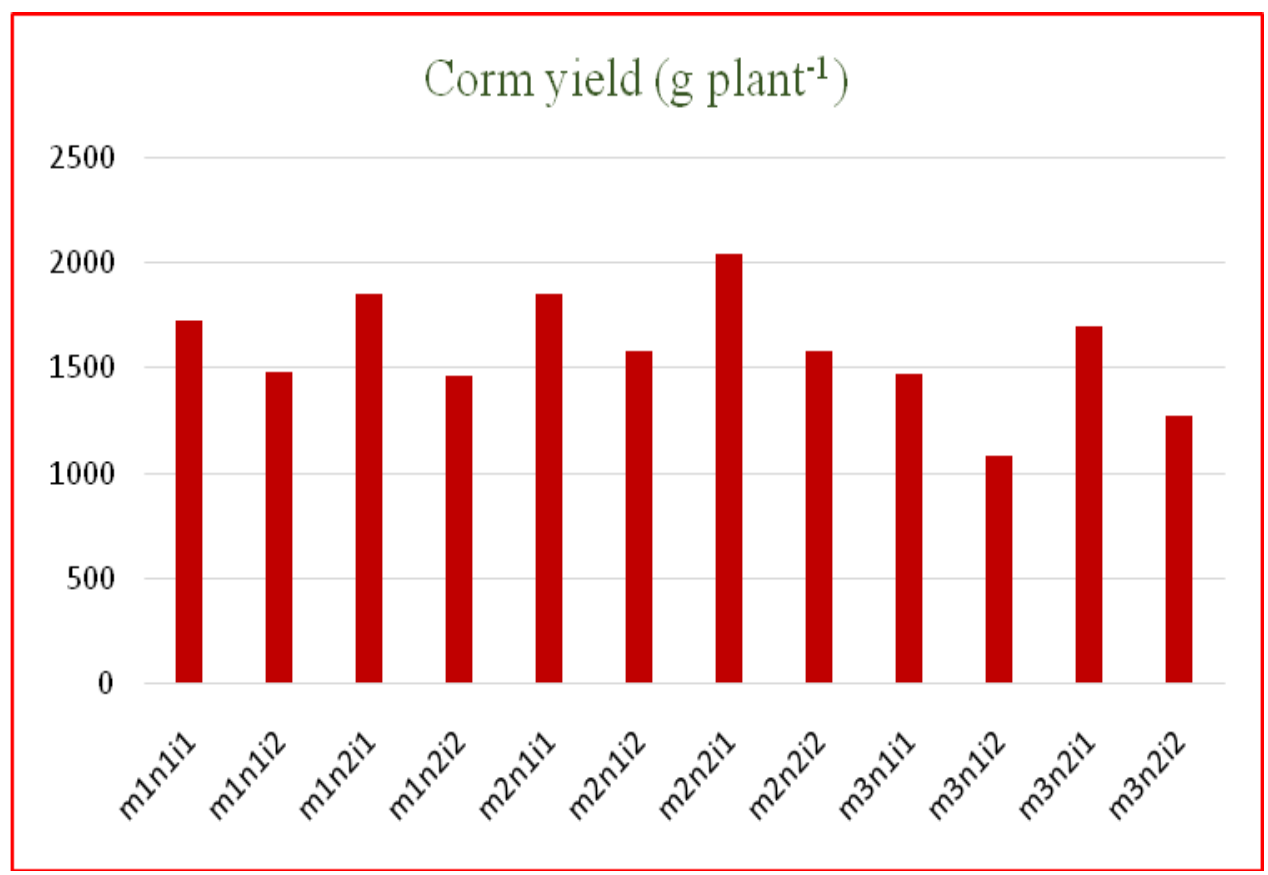

Fig.2 Effect of growth medium (M), nutrient schedule $(\mathrm{N})$ and irrigation schedule (I) on net income, Rs. sack

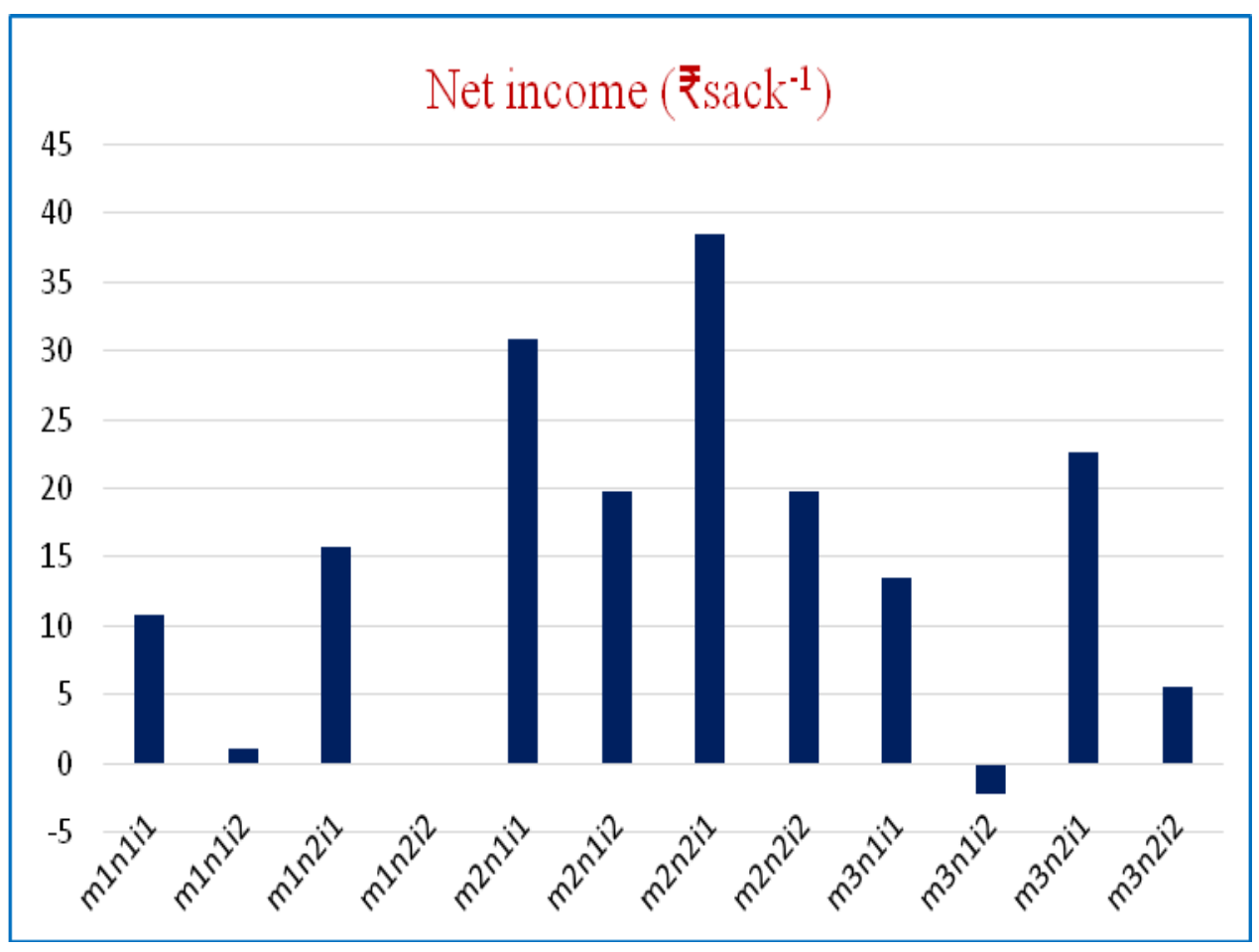


Fig.3 Effect of growth medium (M), nutrient schedule (N) and irrigation schedule (I) on BCR

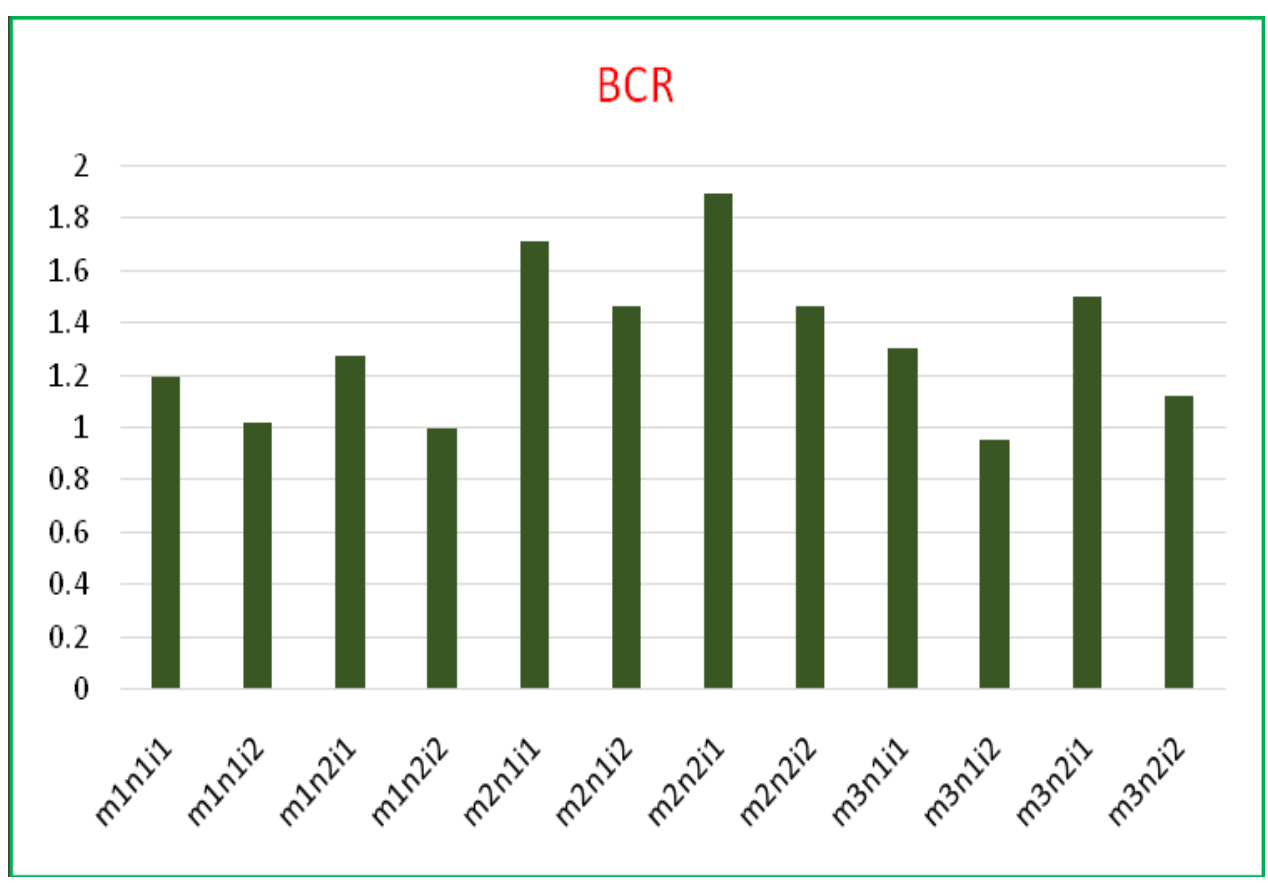

The container cultivation is generally advocated especially in urban homesteads where land availability for cultivation is limited where they can utilize whatever space available around house and on house terraces (Padmanabhan and Swadija, 2002; 2006; 2007; 2015). So the cultivation is to be done by using family labour and not hired labour. Hence, in the present study, cost of labour has not been accounted. Even when hired labour (@ 750 for 100 sacks) is utilized for the initial filling of sacks with growth medium, container cultivation is profitable by using $\mathrm{M}_{2}$ $(9 \mathrm{~kg}$ soil $+3 \mathrm{~kg}$ coir pith $+3 \mathrm{~kg}$ FYM $)$. It is also much safer to use on house terrace since the total weight is only $15 \mathrm{~kg}$ while it is $20 \mathrm{~kg}$ with $\mathrm{M}_{1}(9 \mathrm{~kg}$ soil $+8 \mathrm{~kg}$ sand $+3 \mathrm{~kg}$ FYM $)$. Although the growth medium $\mathrm{M}_{3}(7 \mathrm{~kg}$ soil + $3.75 \mathrm{~kg}$ coir pith $+3 \mathrm{~kg}$ FYM) was not as profitable as $\mathrm{M}_{2}$, it is lighter having only $13.75 \mathrm{~kg}$ weight which is advantageous especially for farming on house terrace. Adopting $\mathrm{M}_{3}$ as growth medium, three or six split application of $\mathrm{N}$ and $\mathrm{K}\left(\mathrm{N}_{1}\right.$ or $\left.\mathrm{N}_{2}\right)$ and irrigation once in three days, it was possible to realize net income of Rs.13.55 $\left(\mathrm{N}_{1}\right)$ or Rs.22.55 $\left(\mathrm{N}_{2}\right)$ and BCR $1.3\left(\mathrm{~N}_{1}\right)$ or $1.5\left(\mathrm{~N}_{2}\right)$ with a corm yield of $1475 \mathrm{~g}$ plant $^{-1}\left(\mathrm{~N}_{1}\right)$ and $1700 \mathrm{~g} \mathrm{plant}^{-1}\left(\mathrm{~N}_{2}\right)$.

It is concluded, based on the results of the study, a cost effective agronomic package for container cultivation of elephant foot yam was formulated. Plastic sacks of uniform size filled with $9 \mathrm{~kg}$ soil $+3 \mathrm{~kg}$ coir pith $+3 \mathrm{~kg}$ FYM can be used as containers. Apply lime @ $10 \mathrm{~g}$ and neem cake @ $100 \mathrm{~g} \mathrm{sack}^{-1}$ and bring the moisture content of growth medium to field capacity. Plant corm pieces of $250 \mathrm{~g}$ (treated with Trichoderma - cow dung slurry and shade dried) in each sack. Apply the recommended dose of $100: 50: 150 \mathrm{~kg} \mathrm{NPK}$ $\mathrm{ha}^{-1}$ for elephant foot yam through organic manures like groundnut cake, bone meal and wood ash. Apply $10 \mathrm{~g}$ of bone meal $\mathrm{sack}^{-1}$ as basal dose and $50 \mathrm{~g}$ of groundnut cake and $100 \mathrm{~g}$ of wood ash $\mathrm{sack}^{-1}$ in six splits at monthly interval starting from one month after planting. Irrigate the crop once in three days during non - rainy periods. 


\section{References}

James, G., and Nair, G.M. 1993.Influence of spacing and seed corm size on yield and yield attributes of elephant foot yam. Journal of Root Crops 19(1): 57-59.

KAU [Kerala Agricultural University] 2011. Package of Practices Recommendations: Crops (14 ${ }^{\text {th }}$ Ed.). Kerala Agricultural University, Thrissur, 360p.

Padmanabhan, V.B., and Swadija, O.K. 2002. Nagarathilum nattinpurangal. Keralakarshakan. 51 (3): 57-59.

Padmanabhan, V.B., and Swadija, O.K. 2006. Swasrayakrishiyiloodeswayamparyapth atha. Yojana 35(1): 49-52.

Padmanabhan, V.B., and Swadija, O.K. 2007. Veettuvalappilumnoorumeni. Keralakarshakan. 53(5): 16-18.

Padmanabhan, V.B., and Swadija, O.K. 2015. Promotion of organic farming in homesteads and urban house terraces- A step to attain nutritional security. Biocultural Heritage and Sustainability, pp240. Oommen O V and Laladhas K P (Eds.). Kerala State Biodiversity Board, Thiruvananthapuram.

Ravi, V., Ravindran, C.S., Suja, G., George, J., Nedunchezhiyan, M., Byju, G., and Naskar, S.K. 2011. Crop physiology of elephant foot yam (Amorphophallus paeoniifolius (Dennst.) Nicolson). Advances in Horticultural Sciences 25(1): 51-63.

Suja, G., Sundaresan, S., John, K.S., Sreekumar, J., and Misra, R.S. 2012. Higher yield, profit and soil quality from organic farming of elephant foot yam. Agronomy for Sustainable Development. 32: 755-764.

Suja, G., John, K.S., Ravindran, C. S., Prathapan, K., and Sundaresan, S. 2010. On farm validation of organic farming technology in elephant foot yam (Amorphophallus paeoniifolius (Dennst.) Nicolson). Journal of Root Crops 36(1): 59-64.

\section{How to cite this article:}

Limisha, N. P. and Swadija, O. K. 2020. Agronomic Package for Container Grown Elephant Foot Yam. Int.J.Curr.Microbiol.App.Sci. 9(08): 244-249. doi: https://doi.org/10.20546/ijcmas.2020.908.028 